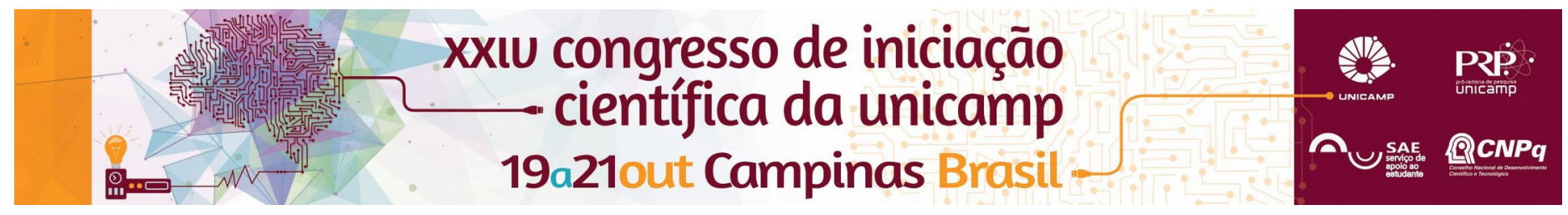

\title{
Levantamento e sistematização da produção teórica sobre a relação entre accountability e participação social
}

\section{Vivaldo Rodrigues de Paula Neto *; Oswaldo Gonçalves Junior}

\begin{abstract}
Resumo
Quando se foca o uso das tecnologias de informação e comunicação (TIC) no setor público, uma visão corrente está associada à ampliação das experiências de governo eletrônico (e-gov), que por sua vez remete ao potencial controle social da gestão pública possibilitado pela maior transparência e accountability, com a disponibilização de dados e informações para acesso público via Internet. Mas como se concretiza o potencial controle social da gestão pública? Qual a relação entre accountability e participação social? Visando obter uma compreensão sobre esta complexa problemática, o presente projeto de pesquisa tem por objetivo: a) realizar levantamento e sistematização de produção teórica que resulte na elaboração de um estado da arte sobre a relação entre os termos accountability e participação social; b) realizar um mapeamento inicial de experiência potencialmente inovadoras nesse campo, dentro do escopo de experiências de governo eletrônico em curso no Brasil.
\end{abstract}

\section{Palavras-chave:}

Accountability; participação social; governo eletrônico.

\section{Introdução}

Em conformidade com o cronograma proposto pelo projeto, o trabalho realizado consistiu no levantamento de materiais sobre a relação entre accountability $\mathrm{e}$ participação social.

Para isso, os portais online Scielo e Google Acadêmico foram consultados, filtrando-se resultados para que somente artigos escritos em língua portuguesa, inglesa ou espanhola fossem evidenciados e utilizando as palavraschave accountability e participação social. No caso do Google, utilizou-se também o mecanismo de alerta para se obter novos conteúdos relacionados ao tema.

\section{Resultados e Discussão}

108 artigos foram encontrados através da plataforma "Google Acadêmico" e 21 artigos foram listados através do Portal Scielo. Os artigos encontrados nos Portal Scielo evidenciam brevemente a característica da amostra encontrada. Dos 21 artigos encontrados, 17 são da língua portuguesa, 5 da língua inglesa e apenas 1 da língua espanhola, sendo 11 da área de Ciências da Saúde (em sua quase totalidade relacionado à saúde pública), 11 do campo das Ciências Humanas

(relacionados em sua maioria à partipação e controle social) e 2 das Ciências Socias Aplicadas (relacionados a governança). Já na plataforma Google Acadêmico, a grande maioria das amostras correspondem a artigos relacionados a controle social(principalmente na área de sáude pública), orçamento participativo e transparência.

\section{Conclusão}

Percebe-se uma tendência descritiva dos artigos, os quais em sua maioria buscam explicitar alguma experiência realizada no setor público, seja no âmbito municipal, estadual ou federal, e que possua relação com participação social e accountability, ainda que existam divergências no entendimento do termo de língua inglesa em sólo nacional. Pode-se perceber através de comparação simples que a plataforma do Google obteve um número maior de resultados, uma vez que evidencia resultados obtidos na internet, de uma forma mais geral, diferentemente do Scielo, o qual evidencia apenas artigos publicados em periódicos científicos indexados e ordenados por aquele Portal. 